\title{
Research on Politics Course Teaching in Middle School from the People-Oriented Perspective
}

\author{
Chang Wang \\ Anshan Normal University, Anshan, Liaoning, 114005, China
}

\begin{abstract}
With the new curriculum reform, we need to promote people-oriented teaching philosophy, highlight the main position of students in the classroom, cultivate the comprehensive quality of students and promote the comprehensive development of students. The essence of politics teaching in middle school is to carry on quality education and it is the main channel of student's training, help students set up correct outlook on life and values. In a people-oriented perspective, it is to mobilize the students' initiative and learning initiative, improve student participation in teaching and create a harmonious and democratic learning environment. However, there are still a lot of problems in the course of political education in middle school in the view of people-oriented, so this paper explores the concept of people-oriented education.
\end{abstract}

Keywords: people - oriented; middle school; political teaching

\section{Introduction}

With the continuous progress of the society and the deepening of the new curriculum reform, we put forward the idea of people-oriented education, pay attention to cultivating students 'subject consciousness and the main body thinking, improve students' comprehensive quality and promote the comprehensive development of students. The political curriculum of middle school in our country has been reformed and innovated constantly. It has made outstanding achievements and raised students' moral consciousness, but it does not have strong persuasiveness and practical effect [1]. Only through the implementation of the "people-oriented" educational philosophy in the teaching 
of politics in middle schools, the passive learning status of students in the traditional teaching can be changed, and the teaching of "people-oriented" to improve students 'sense of participation in class, to stimulate students' awareness of autonomous learning and to create the spirit, to improve the overall quality of students and enhance our comprehensive strength.

\section{The connotation and necessity of human - oriented education}

\subsection{The concept of people-oriented education connotation}

"People-oriented" as the name suggests is the starting point for people, peopledriven, purpose, is the main body of all activities. From a pedagogical point of view, it is the teaching of guiding principles and educational philosophy. From a philosophical point of view, people-oriented in this is the fundamental, neither the original, nor is the nature and nature, is the people as the basis for all activities, people-centred, from the safety, development, survival and more Point of view, to solve all the problems on people [2]. People - oriented education concept is a kind of examination of educational idea from the human - oriented perspective, and emphasizes students' development as the starting point and purpose of teaching. People-oriented education philosophy is to improve the subject status of students and enhance students' subject consciousness, will be people-centred as the principle of education, to stimulate students' potential, and promote students' all-round development.

\subsection{The necessity for people-oriented education philosophy}

Our country is changing from traditional exam-oriented education to modern quality-oriented education, aiming at improving students 'comprehensive quality, emphasizing respect and understanding to students, advocating students to play the dominant position in the classroom and cultivating students' creative spirit and practical ability. The new curriculum reform requires students to highlight the dominant position in the teaching, improve the overall quality of students, promoting the moral, intellectual and physical development of students [3]. In the political lesson teaching, the main channel of the students' quality education is to respond to the new demands of the new curriculum reform. In the teaching process, students should be motivated and motivated, respected the legitimate rights and interests of the students and strengthened their individuality. Nurture, adapt to the needs of the development of the times.

The essence of the guiding ideology of Mao Zedong Thought, Deng Xiaoping Theory and Marxism-Leninism is to strengthen the ideological and moral education of students, to use the scientific theory to arm and improve the students 'socialist moral quality, to cultivate students' ideological and political consciousness, to help Students to establish a correct outlook on life, world outlook and values. The main goal of the political course is to cultivate the socialism successors who are all-round development of morality, intelligence and 
artistry, and to build a socialist country with a harmonious, democratic and prosperous society. Therefore, the concept of people-oriented education is also the essence of quality education in middle school politics curriculum, which fully highlights the humanistic feelings of middle school political courses and displays the value of quality education.

The nature of the political curriculum in middle school is the moral education subject. It aims at cultivating students 'moral quality and individual character. Through the political course, they can educate the students' moral and psychological quality, and make them learn to know and learn. The function of the political curriculum in middle school is mainly directed, normative and individualized. The guiding function is to guide the ideological and moral education and the ideological and moral qualities and personal qualities of middle school students, and the educational value.

\section{Adherence to the "people - oriented" teaching principle in the politics teaching of middle school}

The principle of people - oriented education in middle school politics course is to emphasize students' main body position in the classroom, emphasize students' subjective learning consciousness, and carry out the teaching method according to the age and personality of students to improve students' comprehensive quality. First of all, the principle of democracy in middle school politics teaching is to establish equal and democratic relationship between teachers and students, to break the authoritative teaching environment in traditional education. To improve students 'creative spirit and innovative consciousness, establish students' selfconfidence and cheerful, happy to create, break through the rules, explore the truth of creative personality, cultivate students perseverance, dare to bear setbacks, not afraid of hardship psychological quality. Practical principle is in the classroom, life, students will be emotional attitudes and ideas to show through the action to test the overall quality of students and personal qualities. The subjective principle of the political course in middle school is to highlight the students' dominant position in the classroom. Students' individual differences should be taught according to their aptitude and students' personality development.

\section{The "people - oriented" educational approaches in the politics teaching in middle schools}

\subsection{The politics teaching in secondary schools should dare to innovate}

"People-oriented" educational philosophy is to implement to the educational practice to improve the students in the study of the dominant position in the traditional teaching concept of students in a passive learning position, ignoring the students' sense of autonomy and self-participation in the training, The reform 
of the requirements of the political curriculum to the middle school to innovate and perfect, dare to break the shackles of the traditional examination-oriented education concept, establish the correct view of teaching, students and teachers to achieve the role of education and students to change, highlighting teachers in teaching Play a guiding position, the students play a guiding role, is the growth of students on the road mentor. The cultivation of students 'subjective consciousness can not effectively arouse students' initiative and initiative. Therefore, in the new curriculum reform requirements, we should dare to break the traditional teaching of solid-state thinking, to stimulate students 'subject consciousness, improve students' sense of participation.

\subsection{The politics teaching in secondary schools should pay attention to cultivating students' emotional attitudes}

The political education of middle school is to carry out quality education to students. With the deepening of the new curriculum reform, the cognitive and emotional goals are placed in the same important position, for the basic education problems in-depth analysis and discussion, emphasizing the teaching not only to highlight the student's dominant position, Students 'awareness of independent learning, establish a good learning attitude, to create a good learning atmosphere, to help students establish the correct values and concepts of life, respect for students' emotional attitudes, so as to enhance students acquire knowledge and skills training. Therefore, people-oriented educational philosophy is the prerequisite of basic education. It is the guiding ideology of politics teaching in middle school. It is the theoretical basis of emphasizing students 'moral practice, which is helpful to improve students' comprehensive quality.

\subsection{The politics teaching in middle school should combine theory and life}

The political discipline of middle school is an ideological subject, but also a subject with strong practicality. In the implementation of quality education for students, knowledge theory and life practice should be organically integrated. In the middle school politics teaching, the teacher should carry on the organization and the plan teaching to the student, enhances the student's moral quality through the various practical curriculum. Such as through social services, social surveys, watching movies, exhibitions and other activities to guide students to motto, famous words and related content information collection, or by letting students out of the bulletin, writing survey reports, summary, papers and other forms So that students in practice found true knowledge, in practice, harvest experience. Through the application of the theoretical knowledge of middle school political courses to the practice, according to different forms of teaching context and teaching content of unified and standardized teaching, pay attention to the flexibility of teaching and promote students' all-round development. 


\subsection{The politics teaching in secondary school take a variety of teaching methods}

Diversified teaching methods are mainly three points. First, under the traditional examination-oriented education, the students are indoctrinated and the students are in a passive position of learning. The new curriculum requires that the students' subjective status should be highlighted in the teaching, and the students should be improved. To strengthen communication and exchange between students and grasp the pulse of the students thinking through social phenomena and external information and students on an equal exchange dialogue to mobilize the enthusiasm of students to stimulate students 'desire for knowledge and improve students' awareness of self-learning And independent thinking ability. Third, the traditional mode of teaching students in a passive position, and teachers, although the preparation of teaching more perfect, but often can not effectively improve the quality of teaching, so the practicality of this education is poor. With the deepening of the new curriculum reform, improve the student's learning status and strengthen the students' experience and experience.

\section{Conclusion}

The people-oriented educational philosophy is the development requirements of new curriculum reform, it is also the needs of the times development and the overall demand of students development. In the political lesson teaching, we should carry out the education idea of putting people first, highlight the students' main position in the classroom, pay attention to cultivating students' ideological and moral quality and personal quality, improve students' comprehensive quality, and promote the comprehensive development of students.

\section{References}

[1] Wu Suning. On the Problems and Countermeasures of Politics Teaching in Middle School under the New Curriculum Reform. Journal of Guangxi Teachers Education University (Philosophy and Social Sciences Edition) 55(12), pp.68-70, 2011

[2] Zhang Shizhong. People's Ideological and Political Theory Teaching in Colleges and Universities. Professional circles, 8 (5), pp.87- 91, 20013

[3] Kang Zhuang. "People Oriented" - Construction of Teaching Management of Higher Education in New Media Perspective. News Front, 12(10), pp. 18- 20, 2012

[4] Weng Tian-de. People-centered Self-development - A Brief Discussion on Middle School Writing Teaching under the New Curriculum Criterion. Journal of Fujian Institute of Education, 9(6), pp.58- 61, 2011

[5] Kuang Lizhan. An Analysis of Classroom Teaching Evaluation of Politics Class in Middle School Based on New Curriculum Idea. 8(4), pp.85-87, 2014 